\title{
LEGAL SIGNIFICANCE OF CONSTRUCTION DOCUMENTS: CONSEQUENCES OF NON-IMPLEMENTATION OF CONTRACTUAL REGULATIONS FOR THE CLIENT AND THE CONTRACTOR IN LITHUANIA
}

\author{
Sigitas MITKUS*, Dalia AVERKIENĖ \\ Department of Law, Business Management Faculty, Vilnius Gediminas Technical University, \\ Vilnius, Lithuania \\ *E-mail: sigitas.mitkus@vgtu.lt
}

\begin{abstract}
Purpose - the article discusses the construction documents and their significance enshrined in Contractual Regulations and aims to disclose the consequences of the preparation or non-preparation of the construction documents for the client and the contractor. For this purpose, the general features of construction documents shall be reviewed first, and the certificate of acceptance of construction work and reports shall be analyzed separately.

Findings - the results of the study state that in client/contractor relationship, the rights and duties between the participants to a construction project and the preconditions for the cooperation between the parties in a legal relationship in construction are determined and provided in the construction documents. All construction documents that have been analyzed are drawn up specifically for construction work. On the one hand, the law gives the right or imposes an obligation on to the client and the contractor to sign and deliver the construction documents to another party in a legal relationship in construction. On the other hand, signing (non-signing), submission (non-submission) of the acceptance certificate of construction work and reports can lead to a division of responsibilities between the client and the contractor (who are often business entities), the obligation to eliminate the defects in the work, to compensate for the damage, and to pay for work.
\end{abstract}

Research limitations - though Lithuania has similarities with other EU countries in terms of the legal environment of construction, the generalisation of these results to another context is limited.

Practical implications - the findings could be directly applied in practice. Understanding and using the findings could prevent disputes between owners and contractors in practice.

Originality/Value - there is a lack of publications on the subject. Construction documents regulate the contractual relationship (performance of work, settlement, elimination of defects, etc.) between the client and the contractor. Therefore, proper and timely preparation of these documents is an important part of the implementation of contractual relationship both for business entities and the public using construction results.

Keywords: construction contract, client, contractor, acceptance certificate of work, defects, construction documents.

JEL Classification: M11, L174, K12.

Conference topic: Legal Business Environment.

\section{Introduction}

Construction is one of the political, economic, technical, as well as legal areas covering various aspects. From a broad perspective, construction begins with preparation, alignment, approval of spatial planning documents, foreseeing urbanized areas, the purpose of land plots, and permissible development intensity and height of a specified land parcel. The construction process involves professionals from many fields responsible for spatial planning, construction in urban and rural areas, implementation or improvement of infrastructure (construction of roads, bridges, etc.), economic justification of construction, production of building materials. From a narrow point of view, construction can be understood as construction of a specific building or engineering structure, for which implementation is required not only technical, economic, but also legal preparation ensuring the legitimacy of the activities of participants to construction, determining the execution of their mutual obligations and other legal processes to achieve the result of construction. 
The issues of construction works were examined in different aspects of the scientific doctrine. Formation, execution, pricing and changes, and other legal issues of contracting were analyzed (Saukaliené, 2015; Trinkūniené, 2012; Brazdeikis \& Klimas, 2012; Klimas, 2011; Mitkus \& Cibulskienè, 2009; Mitkus, 2002; Ustinovičius, Andruškevičius, Kutut, Balcevič, \& Barvidas, 2005). However, unlike other sources, this article will analyze one of the aspects of legal construction issues - construction documents in implementing the contractual relationship. The novelty of the article is characterized by the fact the article deals exclusively with the acceptance certificate of construction work and reports. These documents have not been examined in detail in Lithuanian scientific doctrine.

Construction of a construction works, from its commencement to completion and even during the guarantee period, is accompanied by various construction documentation. Depending on the stages of construction, the construction documents can be divided into several groups: pre-construction documents, documents drawn up during construction and post-construction documents. Pre-construction documents may include design documentation of a construction works, technical documents, a construction permit, a certificate of transfer and acceptance of a construction site, and, as required, consent of co-owners of the land plot, etc. Reports, claims, warning letters, acceptance certificates of work, etc. are drawn up during construction of a construction works. Post-construction documents may include a certificate of construction completion or a construction completion declaration, a cadastral survey file, a certificate of noise classification of a building, a building energy performance certificate, geodetic photographs of a plot of land with buildings, etc. The documents required for the construction of construction works are provided for in the Civil Code of the Republic of Lithuania [Civil Code] (2000), the Law on Construction of the Republic of Lithuania and the Technical Construction Regulations.

The construction documentation is diverse and enshrined in different legal acts. Depending on the number of construction documents and the limited scope of this study, it is necessary to define the documents of analyses. Contracting is inevitable in construction, the legal relationship of which is regulated by the Civil Code. Contractual relationship occurs between the client and the contractor when the terms and conditions of the construction contract are being fulfilled. Cooperation between the client and the contractor is essential for the implementation of this legal relationship, which is ensured by the legal norms of the Civil Code regulating the contractual relationship in construction, establishing the preconditions, conditions and consequences of the signing and delivery of the acceptance certificate of work, reports, claims, warning letters. Both, the client and the contractor, have a duty to cooperate with each other, to provide the other party with the aforementioned documents in a timely and proper manner. Compilation/non-compilation, submission/non-submission of construction documents to another party, i.e. implementation/non-implementation of construction contract provisions has corresponding legal (as well as economic) consequences for both the client and the contractor. Thus, the main problem is to reveal aspects of cooperation/noncooperation between the client and the contractor in respect of the above-mentioned construction documents and to demonstrate the importance of mutual obligations of the construction documents (acceptance certificate of work and reports) and the construction process. These documents can lead to the division of responsibilities between the client and the contractor, compensation for damage and loss, the elimination of deficiencies as well as the performance of the construction process, the quality aspects, what is important not only to the client and the contractor, but also to other persons using the results of construction. The practical consequences must be mentioned. The article will help to understand the importance of construction documents and their consequences for the client and the contractor.

The goal of the Study: to disclose the importance of implementation/non-implementation of regulations that determine the contractual relationship between the client and contractor, and the consequences of cooperation based on construction documentation.

To achieve this goal, the following tasks are raised:

1. Disclose the importance of construction documents for cooperation between the client and the contractor.

2. Identify the legal consequences for the client and the contractor caused by compilation /non-compilation of documents.

3. Distinguish some practical aspects of construction documents as a means of protecting the public interest.

Methods of the Study. Theoretical methods such as systematic analysis, logical analysis, generalization, document analysis, and empirical data collection and systematization methods were used to investigate the problem raised. Sources used: scientific articles, dissertations, national and international legislation, case law.

\section{Preconditions for cooperation between the client and the contractor}

All construction documents analyzed in this article are characterized by the fact that they allow the implementation of rights and obligations of legal entities in a contractual relationship during the performance of construction contracts. It should be noted that the relationship in construction can be perceived as a legal relationship between the client and the contractor. In this case, not only the builder (client) and the contractor are assigned to the entities contractual relationship, but as well as the construction manager in cases where a part of the client's functions are transferred to him, thus creating additional participant - scientists - in the contractual relationship (e.g. Saukaliene, 2015). On the other hand, contractual relationship can be interpreted in a broader sense when the participants to construction such as the builder (client), the designer of a construction works, the contractor, the supervisor of construction of a construction 
works and the supplier, as well as other participants, who can participate in the relationship, including State and municipal institutions are considered legal entities in the contractual relationship (e.g. Mitkus, 2002). Given the complexity of the construction process, involving not only the contractor, the client but also many other actors (designers, supervisors, heads of works, even public authorities), the legal relationship in construction, from a broad perspective, is described more accurately and in greater detail. However, when analyzing specific construction documents (acceptance certificates and reports) in this article, which are enshrined in the Civil Code, the fact that these documents are binding on the client and the contractor should be taken into account. Therefore, in this case, the contractual relationship, the entities of which are the client and the contractor having rights and obligations with respect to each other are analyzed in a narrower aspect. The Civil Code provides for the obligations of the contractor and the client, the implementation of which is recorded in the construction documents: acceptance certificates of work, reports, claims, warning letters. Depending on the limited scope of this study, will be analyzed acceptance certificates of work and reports in this paper. Details on the significance of there's documents to the client and contractor in exercising their rights and obligations will be discussed further. However, in implementing the rights and obligations between the parties to the construction contract, mutual cooperation is necessary.

As mentioned above, the contractual relationship is formed and the rights and obligations of their entities are developed on the basis of the construction contract. A construction contract is one of the types of contracts and is therefore subject to the general terms and conditions of the contracts. One of the principles of the contracts is the principle of cooperation between the parties enshrined in international instruments. UNIDROIT Principles of International Commercial Contracts (International Institute of the Unification of the Private Law, 2010) establish cooperation between the contracting parties. Article 5.1.3 of the latter document establishes co-operation between the parties and states that each party is required to cooperate with another party where such cooperation may be expected to be performed by the other party in the performance of its obligations. The obligation of the parties to the contract to cooperate is enshrined in Article 1: 202 of the Principles of European Contract Law [PECL] (n.d.), which governs the obligation for each party to cooperate in order to execute the contract. The importance of cooperation between the parties is also found in other international sources. The authors of the Draft Common Frame of Reference [DCFR] (Von Bar, Clive, \& Schulte-Nolke, 2009) when talking about the principles of contract, distinguish the principles of contractual freedom, reliability, and the principles of loyalty. Loyalty includes the duty of the parties to act honestly, fairly, to cooperate from the start of negotiation until all the terms and conditions of the contract are fulfilled. The parties must cooperate to the extent necessary to fulfil their contractual obligations.

The duty of cooperation of the parties to the contract is also established in Lithuanian positive law. The obligation of cooperation and collaboration of the parties to the contract (including construction contracts) is enshrined in both the General and Special Provisions of the Civil Code (Article 6.38 (3), Article 6.200 (2); Article 6691 (1) of the Civil Code)).

In order to ascertain whether contracting parties to a construction contract can fulfil the duty of cooperation according to construction documents, it is appropriate to discuss the content of the principle of cooperation. In semantic terms, the term "cooperation" is defined as the ability to work together with others (Lithuanian Language Dictionary, n. d.). The content of the principle of cooperation is explained in Lithuanian scientific doctrine. In his commentary on the sixth book of the Civil Code (Bakanas, Bartkus, Dominas et al., 2003), V. Mikelenas notes that the principle of cooperation or collaboration requires the parties to create appropriate conditions for the fulfilment of their obligations, if necessary, to exchange information relevant to the fulfilment of the obligation, and to notify, in a timely manner, on the obstacles arising for the fulfilment of the obligation, and the like. E. Klimas and V. Jurgaitis (Klimas \& Jurgaitis, 2011) discussed the content of the principle of cooperation in scientific research in more detail and provided the following main elements of the principle of the duty of cooperation: the obligation to inform, give instructions, provide assistance, create appropriate working conditions, coordinate actions. The content of the principle of cooperation provided in scientific doctrine is in line with the actions taken based on construction documents enshrined in the Civil Code: reports (information), claims (information, action taken in relation to necessity), warnings, acceptance certificates (efforts of both parties). That implies that the duty of cooperation between the parties - the client and the contractor - to construction is implemented based on the construction documents.

The issue of the duty of cooperation between the contractor and the client is also interpreted in the case law indicating that both the client and the contractor have to submit reports, warning letters, and must cooperate (e.g.: Judgement of the Supreme Court of Lithuania [SCL] of 27 April 2005 in civil case BUAB Atnava v. Vilnius City Municipality Administration; Judgement of the SCL of 17 July 2008 in civil case AG v. AS; Judgement of the SCL of 29 November 2010 in civil case UAB Jaukurai v. UAB Forsythia; Judgement of the SCL of 23 December 2015 in civil case UAB Titano Ranga (Successor - UAB Talesta) v. UAB Mažeikių Varduva; Judgement of the SCL of 2 November 2017 in civil case UAB Vent Guru v UAB Caverion Lietuva).

An overview of the above-mentioned legal norms, scientific doctrine, and case law does not create doubts concerning the duty of cooperation between the contractor and the client. Implementation of this duty is related to appropriate actions such as timely transmission of reports, information, lodging of claims, warnings, the appropriate organization of acceptance and hand over of the result of work, and so on. It can be concluded that the conditions for cooperation between the contractor and the client are based on the construction documents (acceptance certificates, 
reports, claims, and warning letters) established in the Civil Code. The preparation of these documents in particular and their presentation to the other party can confirm whether the duty of cooperation has been fulfilled and to what extent.

\section{Significance for the client and contractor of the construction documents}

\subsection{The legal consequences of the signature of the acceptance certificate of construction work}

The procedure for acceptance of construction work is governed by positive law, i.e. general (Article 6.662) and special (Article 6.694) legal norms of the Civil Code governing the contractual relationship. Detailed practice on the importance of the procedure for the acceptance of construction work is formed by the Supreme Court of Lithuania. In many cases, the Supreme Court of Lithuania acknowledged, inter alia, that under both the provisions of Article 6.692 and Article 6.694 of the Civil Code, the client must accept the result of construction work handed over by the contractor.

Article 6.662(3) of the Civil Code states that the client is obliged to identify obvious defects in the acceptance certificate of work performed. Obvious defects are such defects that can be identified during normal acceptance of work, having no special knowledge and which may emerge later. Such a provision is also formulated in the case law of the Court of Cassation (Judgement of 29 November 2010 in the civil case JSC Jaukuriai v. BUAB Fiorita; Judgement of 11 August 2008 in civil case UAB Pamario Andova v. AZ and ZZ Bailiffs Office; Judgement of 4 March 2015 in civil case UAB SSPC-Klaipeda v. UAB Mitnija). An indication of obvious defects determines whether it will be possible to require the contractor to remove them. Non-indication of obvious defects in the acceptance certificate means that the defects have not been identified and therefore they cannot be invoked later, i.e. it cannot be possible to demand the contractor to remove them or compensate for damage.

The risk of accidental damage or failure of the result of work handed over is passed on to the client from the signature of the acceptance certificate. Such a provision is basically formulated in the general and special legal rules establishing the contractual relationship (Article 6.649(1)(1)(2) and Article 6.682(1) of the Civil Code) regulating that the risk of accidental damage or failure of part or all object until the acceptance by the client, is at the risk of the contractor. This rule presupposes a general assumption that upon acceptance of construction work by the client in accordance with the acceptance certificate of work, the risk of accidental damage or failure of the object falls on the client. The acceptance of the result of construction work is related to the actual and final acceptance of the result of construction work by the client in the sense that the result of construction work passes to the client - it can use it, manage, and dispose of. The acceptance certificate of work draws a line of responsibility for the construction object between the client and the contractor. Therefore, it is important to identify the fact what party was responsible for the object of construction at the moment of its damage or failure. This provision has been confirmed by the Court of Cassation Judgement of 17 December 2010 in civil case BUAB Šimtas aukštų (successor - Lithuanian and Canadian UAB Besserlita) v. G. B.

The payment to the contractor for the work performed is related to the acceptance certificate of work performed. A construction contract is a pecuniary contract. The client must pay for the work performed. Article 6.687 of the Civil Code stipulates that the client must pay for the construction work within the terms and procedures laid down in the construction contract. This means that the legislation gives discretion to the parties to agree on the terms and conditions of payment. The client although must accept (sign the acceptance certificate) defective work, the obligation to pay for unduly performed work does not occur (unless the parties agree otherwise). This confirms that the acceptance certificate must be signed carefully identifying obvious defects in the work performed improperly. The client shall have the right to demand payment for duly completed work from the date of signing this certificate.

It has been mentioned that the contractual relationship is the counter relationship. The contractor's right to receive remuneration from the client is linked to the obligation to perform the agreed work properly. However, the case law of the SCL is not consistent with respect to this question. According to Article 6.655(1) of the Civil Code, the Court of Cassation stated in civil case UAB Parama v. AB VITI (Judgement of 16 December 2011) that in cases where the construction contract does not stipulate that work has to be paid in advance, the client must pay for work after acceptance of work properly performed. The Court of Cassation stated in another civil case UAB Kamesta v. The Lithuanian Road Administration under the Ministry of Transport and Communications (Judgement of 5 July 2016) that failure to hand over the result of work under the acceptance certificate (also when the contractor fails to unilaterally sign such a certificate) does not impose the obligation on the client to pay for work. Unlike the above-mentioned judgements, the Court of Cassation recognised the right of the contractor to the remuneration in civil case $\mathrm{AB}$ Panevežzio statybos trestas v. UAB Arno Vila (Judgement of 22 December 2011) based on the principle of justice, i.e. considered that the client must pay for the work performed to the contractor even in the absence of a signed bilateral or unilateral acceptance certificate. The SCL also recognised in civil case BUAB Glijas v. JSC Serneta (Judgement of 22 December 2011) and in other cases (Judgement of 30 March 2005 in Civil Case S. J. v. G. A.; Judgement of 22 December 2011 in Civil Case AB Panevėžio statybos trestas v. UAB Arno Vila; Judgement of 4 November 2015 in Civil Case BUAB Baltijos Angara, represented by bankruptcy administrator UAB Tytus v. UAB Termoblock; Judgement of 23 March 2017 in Civil Case UAB Tekanas v. UAB Vilstata) that the obligation to pay for the work 
performed also arises from the commencement of actual use of the result of construction work and is not only related to the mutual signing of the acceptance certificate of work performed.

When interpreting the duties of cooperation between entities in the contractual relationship regarding the remuneration for the work performed, it is clear that mutual non-cooperation between the parties does not deny the right of the contractor to the remuneration for the result of work upon the start of actual use of the result of work. On the other hand, even if the fact of non-cooperation between the contractor and the client is established (without presentation of an acceptance certificate) after the contractor has properly performed the work; it is doubtful whether it should be remunerated for the work actually performed started to be used by the client. Having denied such a right of the contractor, it is likely that the principles of justice, reasonableness and proportionality would be denied too. In light of the different case law, it appears that the acceptance certificate of work signed by the parties provides the basis for payment to the client for the work performed. On the other hand, even in the absence of either a bilateral or a unilateral acceptance certificate (unilaterally signed by the contractor), it is recognized that the contractor is entitled to remuneration for the work performed upon the start of actual use of the result of work. Therefore, when deciding the issue of remuneration of the contractor for work, not only the signing of the work acceptance certificate should be considered, but also the circumstances, whether the customer started to use the result of work actually, should be determined.

Summarizing the significance of the acceptance certificate of construction work, the main aspects of its significance for the client and the contractor, illustrated in Figure 1, can be distinguished.

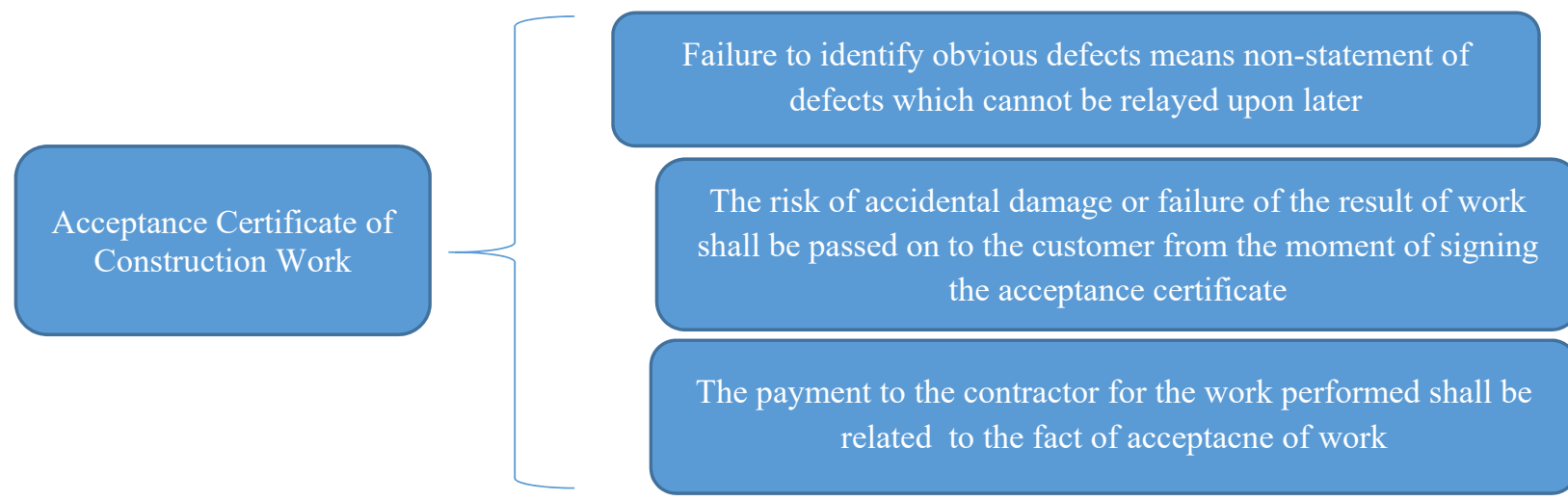

Figure 1. The role of the acceptance certificate of work in respect of third parties (composed by authors)

The acceptance certificate of construction work marks the beginning of the guarantee period. Article 6.698(2) of the Civil Code stipulates that guarantee periods must be calculated from the day of hand over of the result of work for use. The legal norm in this article does not specify the form in which the result of work should be handed over. According to the judgement of the Court of Cassation in civil case UAB ŽVC v. AB Pineka (Judgement of 29 September 2010), the guarantee period can be calculated from the date of the acceptance certificate and from the date of recognition of a construction works as fit for use if the parties have agreed to in the construction contract. If the parties fail to come to an agreement on the start of the guarantee period, this term should be calculated from the date of signature of the acceptance certificate of work, as the result of work is handed over to the customer under this certificate in particular. Based on the case law of the SCL, the handover and acceptance of work are formalized by the certificate (Judgement of 17 January 2007 in civil case Be priekaištu v. UAB Molesta). Claims for work defects may be lodged during the guarantee period not only by the client but also by third parties who acquire and use the object created during construction. In this way, the acceptance certificate affects the public interest, i.e. defines the period from which the term for claiming defects is calculated and creates the preconditions for third parties to defend their rights to the proper quality of the construction object.

\subsection{The legal consequences of reports}

Both the client and the contractor can send reports. Some of the contractor's reports may relate to the increase in prices. The contractor's reports on the necessity to increase the price of work are governed by the provisions of Article 6.65(4) and Article 6.684 (4). Based on these provisions, it may be concluded that the contractor, having informed the customer about the necessity to increase the price of work, has to wait or wait for a reasonable period for a reply from the client whether it agrees with the increased price of work. If the client does not agree with the increased price, the contractor shall have the right to withdraw from the contract and demand payment for the work performed (Article 6.653(4) of the Civil Code). The contractor, who fails to receive a response from the client, shall have the right to suspend the work and claim compensation for damages due to the suspension of work (Article 6.684(4) of the Civil Code). 
The Contractor, who failed to notify the client of additional work in time, shall act at its own risk and have no right to claim remuneration for additional work performed and must execute the contract for the price stipulated in the contract (Judgement of the SCL of 8 April 2015 in civil case UAB Akordas v. Zarasai District Municipality Administration).

The legal consequences of the reports of the contractor on the increase in prices are illustrated in Figure 2.

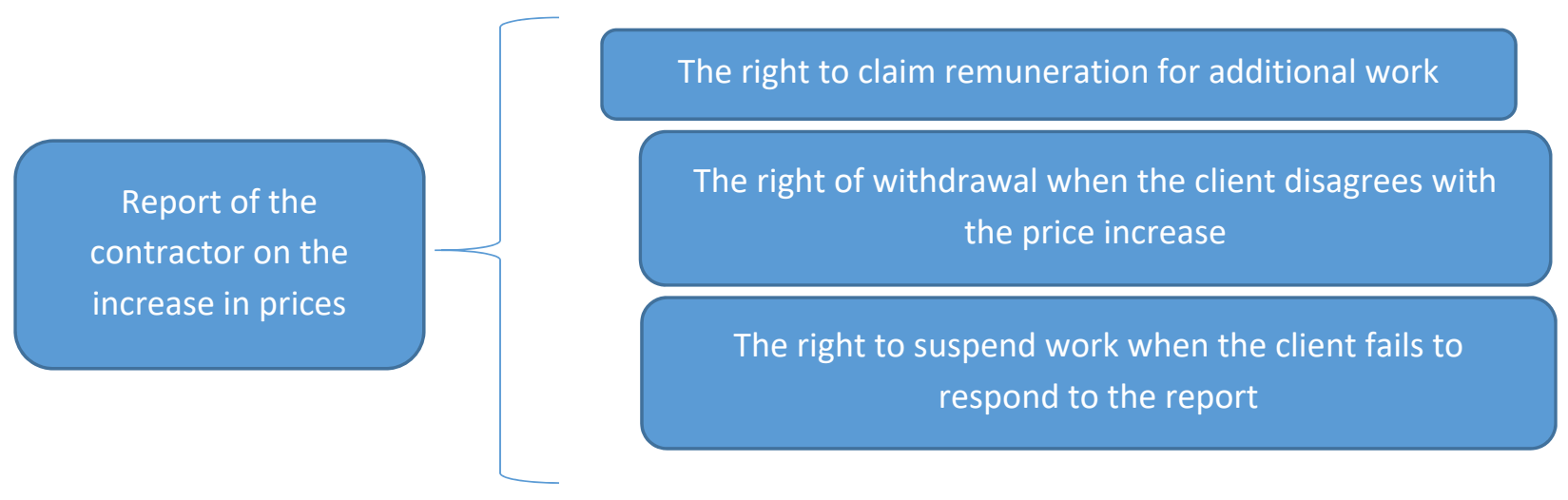

Figure 2. The legal consequences of the reports of the contractor on the increase in prices (composed by authors)

One of the construction documents that give rise to the corresponding rights and obligations to the entities in the contractual relationship is the contractor's report to the client of the readiness to hand over the result of work. Such an obligation is enshrined in Article 6.694(1) of the Civil Code. The contractor's report marks the beginning of acceptance of construction work as the client is informed about the work performed by this report in particular and the intention to hand it over to the client. Only after the contractor informs the client about the work performed and readiness to hand it over, the acceptance of work must be commenced as provided for in Article 6.694(1) of the Civil Code. On the other hand, in the case of such a report of the contractor, but without the client's consent to sign the acceptance certificate, the contractor shall have the right to unilaterally sign the acceptance certificate, the consequences and significance of which have been discussed previously (Article 6.662(6) of the Civil Code).

The legal consequences of the report of the contractor on the handover of work are shown in Figure 3.

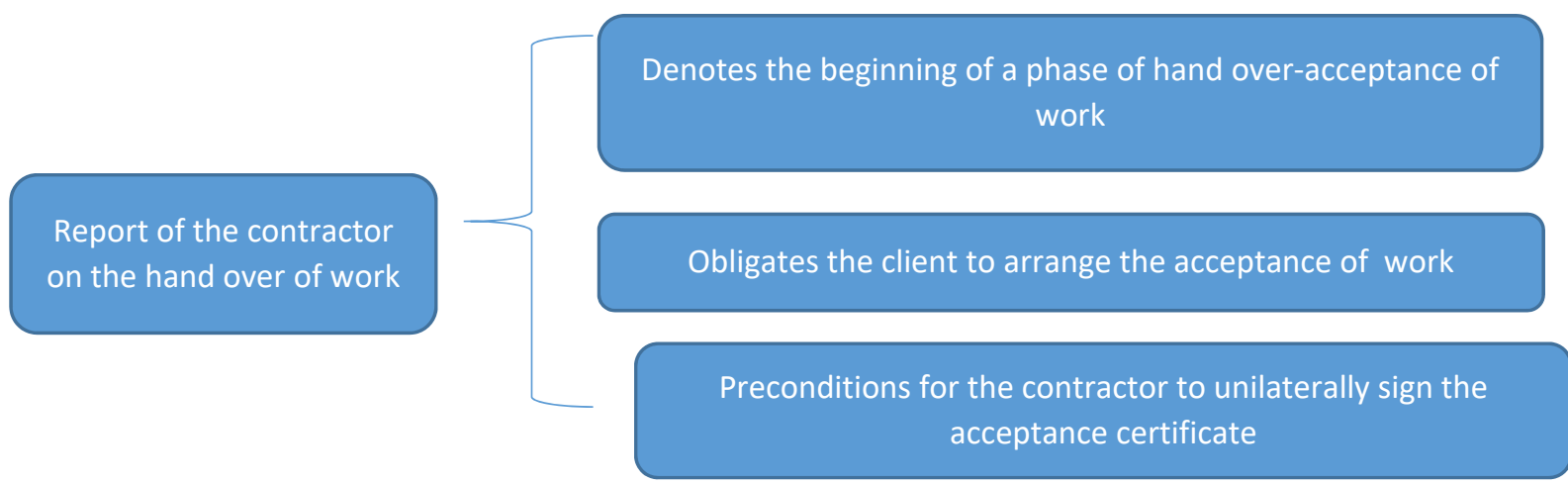

Figure 3. The legal consequences of the report of the contractor on the handover of work (composed by authors)

One of the construction documents is the client's report to the contractor on work defects. When analysing the problems of construction defects and responsibility for them in the scientific doctrine (Saukaliene, 2010), it was emphasized that in the legal system of the Republic of Lithuania construction defect means a defect of work (its result) performed by the contractor. It is also noted that the concept of construction defects should be understood as a defect in the work (the result of work) of inappropriate quality performed by the contractor. The specific nature of the contractual relationship determines the significance of the defect in respect of the quality of the contractual obligation of the contractor rather than the deadline or method of performance of the obligation. Thus, defects related to the quality of work are considered as defects.

The client having noticed any defects in the work or other actions of the contractor during performance of construction work, which may damage the quality of work, must notify the contractor hereof (Article 6.689(2) of the Civil Code). This legal regulation shows that the contractor's responsibility for work defects is not unconditional. Obligations are imposed not only on the contractor but also on the client in order to perform work of the proper quality and fulfil the conditions of the construction contract. 
Another report of the client on work defects is possible after the completion of construction work and acceptance of the result of work. The obligation of the client to notify the contractor on defects of work after the acceptance of work is regulated by Article 6.662(4) and Article 6.697(5). The report of the client to the contractor on the defects of work after the expiry of the guarantee period in respect of the quality of work provided by law (as defined in Article 6.664 of the Civil Code) would be meaningless. The contractor shall normally be liable for defects identified during the guarantee period under Article 6.697(3) (e.g. Judgement of the SCL of 1 December 2009 in civil case AB If P\&C Insurance AS v. UAB Irengimas; Judgement of 27 September 2010 in civil case UAB ŽVC v. AB Pineka; Judgement of 29 November 2004 in civil case AB Panevėžio statybos trestas v. UAB AK Aviabaltika). After the expiration of the guarantee period, the contractor shall not be obliged to eliminate the defects in the work. It should be also noted that the period of limitation (the period during which an action can be brought to court (Averkiene, 2015) begins on the date of the statement of defects if the defects are reported within the guarantee period (Article 6.667 (3) of the Civil Code).

The significance of the client reports can be represented graphically in Figure 4.

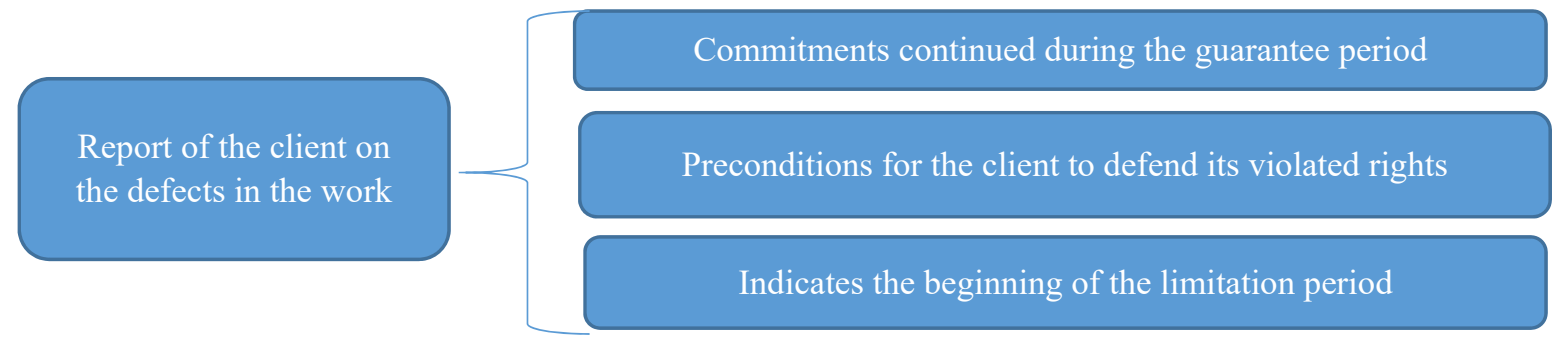

Figure 4. The significance of the client reports (composed by authors)

Based on analysis of legal norms and case law, it may be summarized that the reports of the client on defects in the work can be provided to the contractor when performing construction work or after the acceptance of the result of work, and occurrence of defects during the guarantee period. These reports provide the preconditions for the client to defend its violated rights by the means provided for by law and to lodge claims.

\section{Conclusions}

1. Construction documents analysed in the article, such as acceptance certificate of construction work and reports ensure the implementation of mutual rights and obligations and cooperation between entities in the contractual relationship.

2. Timely and appropriate compilation of construction documents, their signing and service to the other party in contractual relationship determines the division of responsibilities between the client and the contractor, realization of the right to remuneration for the work performed, implementation of the obligation to eliminate defects, distribution of the loss incurred, and other rights and obligations.

3. Construction is related to the public interest because, depending on the purpose of the building, specific persons or an indefinite number of persons may use the results of construction (in terms of public buildings, engineering facilities, etc.). As a result, the quality of construction is of paramount importance, which, among other things, can be guaranteed by the professionalism of the contractor. In this respect, the contractor's warnings to the client regarding the materials, works, the chosen method of execution of works and other construction elements should be distinguished. Construction documents and related consequences (suspension of work) affect the public interest. Influence of the acceptance certificate of construction work on the public interest of construction works manifests itself in the fact that this certificate establishes the beginning of the guarantee period. During the guarantee period, third parties may also bring claims against defects in the work and their removal.

\section{References}

Averkienė, D. (2015). Procedural terms: the premise of a fair and efficient civil process (Doctoral dissertation). Mykolas Romeris University, Vilnius, Lithuania.

Bakanas, A., Bartkus, G., Dominas, G., et al. (2003). Commentary on the civil code of the Republic of Lithuania (6 book, Obligation Law, Vol. 1). Vilnius: Justitia.

Brazdeikis, A., \& Klimas, E. (2012). Price change during the execution of the construction contract. Law, 85, 113-129.

Civil Code of the Republic of Lithuania. (2000). Retrieved from https://www.infolex.lt/ta/100228

International Institute of the Unification of the Private Law. (2010). UNIDROIT principles of international commercial contracts. Retrieved from https://www.unidroit.org/instruments/commercial-contracts/unidroit-principles-2010 
Mitkus, S.; Averkienè, D. 2019. Legal significance of construction documents: consequences of non-implementation of contractual regulations for the client and the contractor in Lithuania

Klimas, E., \& Jurgaitis, V. (2011). Interpretation and content of the duty to cooperate in modern contract law. Social Sciences Studies, 3(1), 329-346.

Klimas, E. (2011). The principle of duty of co-operation, application of this principle and its significance in the contractual relationship (Doctoral dissertation). Vilnius University, Vilnius, Lithuania.

Lithuanian Language Dictionary. (n.d.). Retrieved from https://www.lkz.lt/Visas.asp?zodis=bendradarbiauti\&lns=-1\&les=-1

Mitkus, S., \& Cibulskienė, R. (2009). Construction contract: qualification problems. Law, 70, 36-50.

Mitkus, S. (2002). Construction Law. Vilnius: Technika.

Principles of European Contract Law (n.d.). Retrieved from https://www.trans-lex.org/400200/_pecl/\#head_12

Saukalienè, K. (2010). Construction defects and problems of responsibility for them. Social Sciences Studies, 2(6), 243-257.

Saukalienè, K. (2015). Problematic aspects of acquisition and loss of ownership in the contractual relationship (Doctoral Dissertation). Mykolas Romeris University, Vilnius, Lithuania.

The judgement of the Supreme Court of Lithuania of 29 November 2010 in Civil Case UAB Jaukurai v. UAB Forsitia, Case No. $3 \mathrm{~K}-3-469 / 2010$.

The judgement of the Supreme Court of Lithuania of 1 December 2009 in Civil Case AB If P\&C Insurance AS v. UAB Irengimas, Case No. 3K-3-516/2009.

The judgement of the Supreme Court of Lithuania of 11 August 2008 in Civil Case UAB Pamario Andova v. A. Z. in Z. Z. Bailiffs Office, Case No. 3K-3-371/2008.

The judgement of the Supreme Court of Lithuania of 16 December 2011 in Civil Case UAB Parama v. AB VITI, Case No. 3K-3$521 / 2011$.

The judgement of the Supreme Court of Lithuania of 17 December 2010 in Civil Case BUAB Šimtas aukštų (successor - Lithuanian and Canadian UAB "Besserlita") v. G. B., Case No. 3K-3-505/2010.

The judgement of the Supreme Court of Lithuania of 17 January 2007 in Civil Case TUB Is priekaištu v. UAB Molesta, Case No. $3 \mathrm{~K}-3-17 / 2007$.

The judgement of the Supreme Court of Lithuania of 17 July 2008 in Civil Case A. G. v. A. S., Case No. 3K-3-396/2008.

The judgement of the Supreme Court of Lithuania of 22 December 2011 in Civil Case AB Panevėžio statybos trestas v. UAB Arno Vila, Case No. 3K-3-536/2011.

The judgement of the Supreme Court of Lithuania of 22 December 2011 in Civil Case BUAB Glijas v. UAB Serneta, Case No. 3K$3-536 / 2011$.

The judgement of the Supreme Court of Lithuania of 23 December 2015 in Civil Case UAB Titano ranga (successor - UAB Talesta) v. UAB Mažeikių Varduva, Case No. 3K-3-681-378/2015.

The judgement of the Supreme Court of Lithuania of 23 March 2017 in Civil Case UAB Tekanas v. UAB Vilstata, Case No. 3K-3$143-695 / 2017$.

The judgement of the Supreme Court of Lithuania of 2 November 2017 in Civil Case UAB Vent Guru v. UAB Caverion Lietuva, Case No. e3K-3-371-313/2017.

The judgement of the Supreme Court of Lithuania of 27 April 2005 in Civil Case BUAB Atnava v. Vilnius City Municipality Administration, Case No. 3K-3-235/2005.

The judgement of the Supreme Court of Lithuania of 29 November 2004 in Civil Case AB Panevėžio statybos trestas v. UAB AK Aviabaltika, Case No. 3K-3-652/2004.

The judgement of the Supreme Court of Lithuania of 29 September 2010 UAB ŽVC v. AB Pineka, Case No. 3K-7-62/2010.

The judgement of the Supreme Court of Lithuania of 30 March 2005 in Civil Case S. J. v. G. A., Case No. 3K-3-207/2005.

The judgement of the Supreme Court of Lithuania of 4 March 2015 in Civil Case UAB SSPC-Klaipeda v. UAB Mitnija, Case No. $3 \mathrm{~K}-3-112-313 / 2015$.

The judgement of the Supreme Court of Lithuania of 8 April 2015 in Civil Case UAB Akordas 1 v. Zarasai District Municipality Administration, Case No. 3K-3-202-248/2015.

The judgement of the Supreme Court of Lithuania of 4 November 2015 in Civil Case BUAB Baltijos angarai, represented by bankruptcy administrator UAB Tytus v. UAB Termoblock, Case No. 3K-3-558-421/2015.

The judgement of the Supreme Court of Lithuania of 5 July 2016 in Civil Case UAB Kamesta v. The Lithuanian Road Administration under the Ministry of Transport and Communications, Case No. 3K-3-363-611/2016.

Trinkūnienè, E. (2012). Construction and real estate transactions. Vilnius: Technika.

Ustinovičius, L., Andruškevičius, A., Kutut, V., Balcevič, R., \& Barvidas, A. (2005). Verbal analysis of contracts of engineering and design of buildings. Technological and Economic Development, XI(1), 36-49. https://doi.org/10.3846/13928619.2005.9637681

Von Bar, C., Clive, E., \& Schulte-Nolke, H. (2009). Principles, definitions and model rules of european private law. Draft Common Frame of Reference (DCFR). Outline Edition. Munich: European law publishers GmbH. 